\title{
Evaluation of marginal and internal adaptations of posterior all-ceramic crowns fabricated with chair-side CAD/CAM system: an in vitro study
}

\author{
Merve Bankoğlu Güngör, Aylin Doğan, \\ Bilge Turhan Bal, Seçil Karakoca Nemli* \\ Department of Prosthodontics, Faculty of Dentistry, Gazi \\ University, Ankara, Turkey
}

\begin{abstract}
OBJeCtive: Advances in chair-side Computer-Aided Design I Computer-Aided Manufacturing (CAD/CAM) technology and materials science currently enable the fabrication of highly esthetic restorations for the anterior and posterior teeth. However, there is a lack of evidence regarding the marginal and internal adaptations of new CAD/CAM materials. The objective of this study was to evaluate the marginal and internal adaptations of posterior all-ceramic restorations fabricated from contemporary restorative materials with chair-side CAD/CAM system.
\end{abstract}

Materials and Method: An artificial mandibular right first molar tooth was prepared according to standard tooth preparation procedures, and standard models of the prepared teeth were obtained. All-ceramic restorations $(n=10)$ were fabricated from seven different CAD/CAM blocks (IPS e.max CAD, Lava Ultimate, Incoris TZI, Incoris ZI, Vita Suprinity, Vita Enamic, and GC Cerasmart). The marginal and internal adaptations were measured with silicone replicas, which were sectioned with a thin lancet. The discrepancy between the die and the inner surface of the restoration was examined at $50 \times$ magnification by using a light microscope with digital camera. Four reference points were examined at each buccal-lingual section and eight reference points were examined at each mesial-distal section. The results were evaluated by two-way analysis of variance (ANOVA) followed by Tukey HSD test $(\alpha=0.05)$.

RESULTS: The values obtained from marginal-internal areas were generally greater than those in the marginal areas. Significant differences were found between the materials.

Received: April 14, 2017; Accepted: July 27, 2017

${ }^{*}$ Corresponding author: Dr. Secil Karakoca Nemli, Department of

Prosthodontics, Faculty of Dentistry, Gazi University, Emek, Ankara, Turkey;

E-mail: secilkarakoca@yahoo.com
The statistical analysis revealed that there was an interaction between the material type and the location of the reference points $(p<0.05)$; the lowest values were observed in axial areas, and the highest values were observed in occlusal areas.

CONCLUSION: All materials showed low marginal and internal discrepancies which were considered clinically acceptable.

KEYWORDS: Ceramics; computer-aided design; dental marginal adaptation

Citatıon: Bankoğlu Güngör M, Doğan A, Turhan Bal B, Karakoca Nemli S. Evaluation of marginal and internal adaptations of posterior all-ceramic crowns fabricated with chair-side CAD/CAM system: an in vitro study. Acta Odontol Turc 2018;35(1):1-8

EdıTOR: Alper Çağlar, Başkent University, Ankara, Turkey

Copyright: @ 2018 Bankoğlu Güngör et al. This work is licensed under a Creative Commons Attribution License. Unrestricted use, distribution and reproduction in any medium is permitted provided the original author and source are credited.

\section{INTRODUCTION}

Computer-aided design (CAD) and computer-aided manufacturing (CAM) have been popular in recent years. These digital techniques afford several advantages in the dental practice. ${ }^{1}$ Capturing images of prepared, adjacent, and opposing teeth, which is the first step in the CAD/CAM process, eliminates the need for making an impression using elastomeric impression material. Therefore, concerns about the dimensional stability of impression materials and the pouring of stone cast can be eliminated, and the impression process can be significantly simplified. ${ }^{2-4}$ The design and milling stages of the CAD/CAM process would decrease manufacturing costs by reducing the time spent in the laboratory by technicians and allowing clinicians to fabricate chair-side restorations. ${ }^{5}$ Milling the restoration from an industrially sintered ceramic block with a very homogenous structure improves the quality of the material compared with conventional 
ceramic processing techniques. ${ }^{4,6}$ The adaptation of restorations may be improved by combining intraoral scanning and digital milling. ${ }^{3,6-9}$ Furthermore, CAD/CAM technology enables the use of a wide range of esthetic dental materials to restore both anterior and posterior teeth. ${ }^{6,10-15}$

The adaptation of a restoration is determined by measurements of its marginal and internal gaps, which are important factors for the long-term clinical success of restorations. Good marginal adaptation ensures the gingival health, and results in less cement dissolution and few instances of caries and discoloration. ${ }^{16-19}$ An ideal internal adaptation improves mechanical properties, such as retention, strength, and resistance..$^{20,21}$ The adaptation of conventionally-fabricated all-ceramic restorations in the laboratory is a sensitive technique that may be affected by several factors such as the impression material and technique, disinfection, the storage time and conditions of the impression before pouring the stone cast, application of the die spacer, and the investment and casting or pressing process. ${ }^{1,22}$ There are also inherent factors affecting the adaptation of milled restorations: the accuracy of the scanner, the software design, spacer setting, the precision of the milling unit, and the properties of milled material in CAD/CAM technology. ${ }^{22-24}$ However, recent CAD/ CAM systems use highly accurate scanners, advanced software, and precise milling devices with advanced technology. ${ }^{25}$ The accuracies of scanners ${ }^{26,27}$ and precision of milling devices ${ }^{3,28}$ have been confirmed by recent studies. Therefore, restorative material properties have gained interest for the accuracy of the CAD/CAM fabrication process.

A wide range of esthetic CAD/CAM ceramic materials has recently been introduced ranging from relatively weak feldspathic and leucite-reinforced glass ceramics to high-strength lithium disilicate glass ceramics, zirconia, and new hybrid ceramics. ${ }^{6,10-15,29}$ The mechanical properties of some of these materials have been investigated. ${ }^{23}$ However, there is little information about the marginal and internal adaptations of CAD/ CAM ceramic materials in the literature; moreover, such studies have been limited to lithium disilicate and zirconia. The marginal and internal adaptations of CAD/CAM fabricated lithium disilicate crowns have been comparable or better than that of conventionally fabricated crowns., ${ }^{1,20,22}$ Zirconia copings have also exhibited marginal and internal adaptation values falling within the clinically acceptable range. ${ }^{6,7,19}$ To the best of our knowledge, there are no studies pertaining to the adaptation of recently introduced CAD/CAM materials (e.g. monolithic zirconia and hybrid ceramics).

The objective of this in vitro study was to evaluate the marginal and internal adaptations of chair-side CAD/CAM ceramic crowns fabricated from different prefabricated blocks. The null hypothesis for this study was that marginal and internal adaptations of chairside posterior crowns would be similar for different materials.

\section{Materials and Method}

\section{Specimen preparation}

An artificial mandibular right first molar tooth (ANA-4 ZE Standard Replacement Teeth, Frasaco $\mathrm{GmbH}$, Tettnang, Germany) was prepared for an all-ceramiccrown according to standard tooth preparation procedures. The tooth preparation yielded a $1.2 \mathrm{~mm}$ deep chamfer, a $2 \mathrm{~mm}$ occlusal reduction, and 6-degree angled axial walls. The prepared tooth was mounted on a Typodont (ANA-4V Advanced Standard Typodont, Frasaco $\mathrm{GmbH}$ ). Impressions were taken with a polyvinyl siloxane (PVS; Hydrorise Monophase, Zhermack Spa, Badia Polesine, Italy) impression material and a custom impression tray. Custom trays were fabricated using visible light polymerizing acrylic resin (Triad VLC, Dentsply Caulk, York, PA, USA), which ensured a minimum impression material thickness of $3 \mathrm{~mm}$. One-step dual viscosity impression was made. A lightbody PVS impression material (Hydrorise light body, Zhermack Spa) was mixed using a manual dispenser system and injected on and around the prepared tooth. Next, a heavy body impression material (Hydrorise Maxi Heavy, Zhermack Spa) was mixed using a dynamic mixer. A custom impression tray was filled with this heavy body impression material. Then, the impression tray was positioned on the typodont. All impressions were taken under standard room conditions by the same investigator. To ensure proper polymerization of the impression material, the impressions were allowed to set three times longer than the duration recommended by the manufacturer. The impressions were visually inspected using a magnifying glass (Loupe opt-on, Orange Dental, Biberach, Germany). Then, the casts were poured using a type IV dental stone. The dental stone was mixed in accordance with the water/ powder ratio recommended by the manufacturer and poured into the impressions under constant vibration. The casts were allowed to set for $1 \mathrm{~h}$. Next, the casts were separated from the impressions and the prepared tooth was visually inspected (Loupe opt-on; Orange Dental) for irregularities by a single operator. A total of 70 standard casts were fabricated for 7 groups. Each group was assigned to a particular CAD/CAM material to be milled in the CEREC system. The casts were mounted in semi-adjustable articulator (Stratos 100; Ivoclar Vivadent, Schaan, Liechtenstein) in a maximum intercuspal position. Full-arch digital impressions were obtained using an intraoral scanner (CEREC Omnicam, Sirona Dental Systems, Bensheim, Germany) from the mandibular and maxillary casts and the buccal side of the casts. The maximum intercuspal positions of virtual models were calculated using buccal images after models were generated by the CAD software (inLab SW 4.2; Sirona Dental Systems). Then, the model axis was set, and the restoration margins were determined. The restorations were designed by selecting a cement thickness of $80 \mu \mathrm{m}$. Manual adjustment was not made to the marginal aspects of the designs except suggestions by the software. Minor adjustments were made to the 


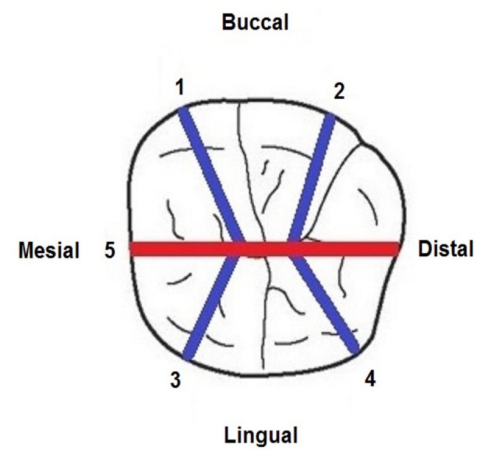

Figure 1. Sections of reference points

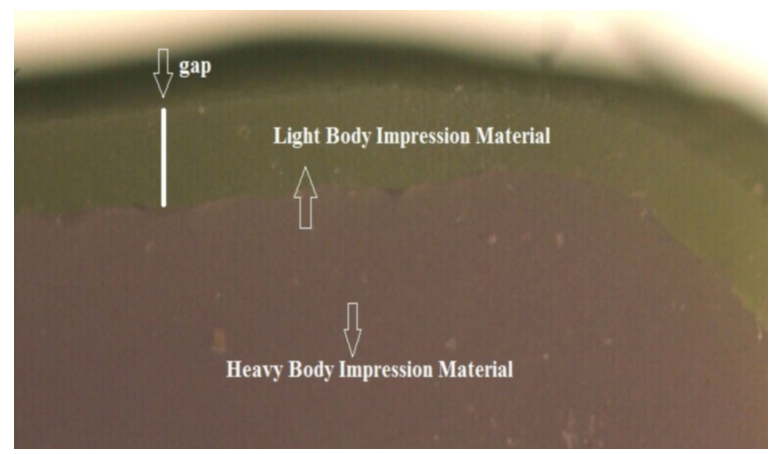

Figure 3. Microscopic view of silicone replica at 50x magnification

occlusal surface of the restoration to ensure a similar material thickness for all specimens, if necessary. All of the ceramic crowns were milled in a milling unit (CEREC MC XL; Sirona Dental Systems). The crowns were cleaned with water in an ultrasonic cleaner to remove milling residue from the CAD/CAM milling machine. Then, each group was processed according to the procedures recommended by the manufacturer as follows:

Group 1: IC (IPS e.max CAD, Ivoclar Vivadent); lithium disilicate crowns,

Group 2: LU (Lava Ultimate, 3M ESPE, St. Paul, MN, USA); resin nano-ceramic crowns,

Group 3: TZI (InCoris TZI, Sirona Dental Systems); monolithic zirconia crowns,

Group 4: VS (Vita Suprinity, Vita Zahnfabrik, Bad Säckingen, Germany); zirconia-reinforced glass ceramic crowns,

Group 5: VE (Vita Enamic, Vita Zahnfabrik); hybrid ceramic crowns,

Group 6: ZI (InCoris ZI core, Sirona Dental Systems); zirconia crowns,

Group 7: GC (GC Cerasmart, GC Corporation, Tokyo, Japan); flexible nano-ceramic crowns.

The milled crowns in Groups 1 and 4, which were in a crystalline intermediate phase, were crystallized

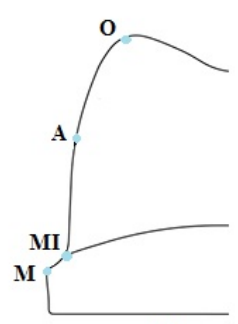

(a)

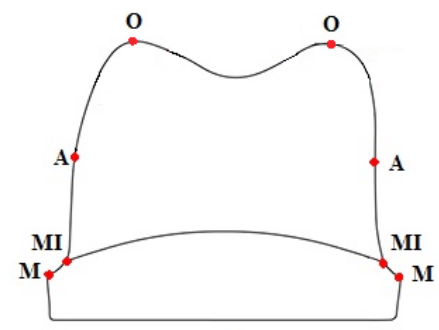

(b)
Figure 2. Schematic diagrams of reference points; (a) Reference points from buccal-lingual section, (b) Reference points from mesial-distal section (M: marginal, Ml: marginal-internal, A: axial, O: occlusal)

in a porcelain furnace (Programat P300; Ivoclar Vivadent). The milled crowns in Group 3, which were in a partially sintered phase, were dried and sintered in a sintering furnace (InFire HTC; Sirona Dental Systems). No processing was required for the milled crowns in Groups 2, 5, and 7. For the crowns in Group 6 , the zirconia cores were veneered with CAD-CAMfabricated feldspathic ceramic (CEREC Block; Sirona Dental Systems), which was bonded to the cores using a resin cement (Panavia 2.0; Kuraray, Osaka, Japan). Removable dies were separated from the casts and duplicated from a Co-Cr alloy powder (Eos Cobalt Chrome SP2; Eos GmbH, Krailling, Germany) using direct-laser sintering technology (Eosint M 270; Eos $\mathrm{GmbH}$ ). The metal dies were used for measuring the internal and marginal adaptations of the crowns.

\section{Measurement of marginal and internal gaps}

Silicone replica technique was used to measure the internal and marginal adaptation. To obtain replicas, a light-body impression material (Variotime; Heraeus Kulzer GmbH, Hanau, Germany) was filled in all of the ceramic crowns thoroughly and then the crowns were placed on the metal dies. After the light-body impression material was set, the crowns were removed from the metal dies. Heavy-body impression material (Variotime; Heraeus Kulzer $\mathrm{GmbH}$ ) was placed in the crowns on the light-body impression material. Replicas of the cast teeth specimens were sectioned with a thin lancet to 1 $\mathrm{mm}$ thickness and 5 sections were obtained for each replica (Figure 1). For sections 1-4, four reference points (Figure 2a) were determined, and for section 5 , eight reference points (Figure $2 b$ ) were determined. The reference points were set at the marginal $(M)$, marginal-internal (MI), axial (A), and occlusal (O) areas, and the mean values were calculated for each reference point. Silicone replicas were examined using a light microscope at 50× magnification (Figure 3) and Leica Qwin Plus program (Leica Microsystems Imaging Solutions Ltd, Cambridge, UK).

\section{Statistical analysis}

The statistical analysis was performed using software (SPSS version 20.0, SPSS Inc, Chicago IL, USA). The 
Table 1. Tests of between-subjects effects

\begin{tabular}{|c|c|c|c|c|c|}
\hline Source & $\begin{array}{l}\text { Type III Sum of } \\
\text { Squares }\end{array}$ & df & Mean Square & $\mathbf{F}$ & Sig. \\
\hline Corrected Model & 7.817 & 27 & $289,502.947$ & 42.063 & 0.000 \\
\hline Intercept & 6.102 & 1 & 6.102 & $8,865.942$ & 0.000 \\
\hline Material & $759,765.976$ & 6 & $126,627.663$ & 18.398 & 0.000 \\
\hline Location & $6,482,404.49$ & 3 & $2,160,801.496$ & 313.953 & 0.000 \\
\hline Material * Location & $574,409.104$ & 18 & $31,911.617$ & 4.637 & 0.000 \\
\hline Error & 1.137 & 1652 & $6,882.566$ & - & - \\
\hline Total & 8.021 & 1680 & - & - & - \\
\hline Corrected Total & 1.919 & 1679 & - & - & - \\
\hline
\end{tabular}

df: degrees of freedom, F: F-ratio, Sig.: significance ( $p$ value)

Table 2. Mean values $(\mu \mathrm{m})$ and standard deviations $(S D)$ of tested materials

\begin{tabular}{|c|c|c|c|c|}
\hline Material & Marginal mean (SD) & Marginal-internal mean (SD) & Axial mean (SD) & Occlusal mean (SD) \\
\hline IC & $195.19(83.87)$ & 219.35 (82.69) & $99.12(62.55)$ & $332.49(93.68)$ \\
\hline LU & $143.85(65.21)$ & $173.47(85.50)$ & $104.13(46.45)$ & $276.13(77.34)$ \\
\hline TZI & $212.50(101.45)$ & $227.11(86.95)$ & $143.44(39.55)$ & $277.57(72.18)$ \\
\hline VS & $157.48(66.65)$ & $167.53(74.53)$ & $95.50(37.06)$ & $270.10(83.75)$ \\
\hline VE & $122.23(44.64)$ & $170.10(77.66)$ & $94.08(41.15)$ & $271.63(64.50)$ \\
\hline ZI & $167.44(100.66)$ & $214.16(110.09)$ & $112.15(48.26)$ & 220.37 (126.31) \\
\hline GC & 203.65 (127.36) & 202.05 (97.44) & $126.25(71.67)$ & 337.27 (134.81) \\
\hline
\end{tabular}

IC: IPS e.max CAD, LU: Lava Ultimate, TZI: IncorisTZI, VS: Vita Suprinity, VE: Vita Enamic, ZI: Incoris ZI, GC: GC Cerasmart

data were evaluated using two-way analysis of variance (ANOVA; $\alpha=0.05$ ). The Tukey HSD test was used to measure differences between groups.

\section{RESULTS}

The ANOVA test revealed that there was an interaction between the material type and the location of the reference points $(p<0.05$; Table 1$)$. The mean values and standard deviations of the materials as a function of the reference points are given in Table 2. It was observed that the lowest and highest values were in the axial, and the occlusal areas, respectively. Larger gaps were observed in Groups 3 (TZI) and 7 (GC), followed by Group 1 (IC). The values of Group 2 (LU), Group 4 (VS), Group 5 (VE), and Group 6 (ZI) were similar. The values in the marginal-internal areas were generally higher than those in the marginal areas. Pairwise comparisons between the tested materials are shown in Table 3.

\section{Discussion}

In this in vitro study, the marginal and internal adaptations of CEREC-fabricated ceramic crowns were investigated. A wide range of prefabricated blocks including glass ceramics, zirconia cores, translucent zirconia, and hybrid materials which are suitable for posterior crowns were used as crown material. To the best of our knowledge, no previous study has evaluated the marginal and internal adaptations of crowns fabricated from these materials. The data from this in vitro study led to the rejection of the research hypothesis that marginal and internal adaptations of posterior CAD/CAM-fabricated crowns would be similar for different materials.

Adaptation between the tooth and the restoration is important for the long-term success of restorations. ${ }^{5,7}$ To measure the marginal and internal adaptations, several techniques have been used 1,5,19,20,22; however, a single standard protocol is not available in the literature. In the present study, the silicone replica technique, which is used to determine the in vivo gap between tooth and crown surfaces, has been used to evaluate the marginal and internal adaptation. This method is reliable and non-invasive for indirect restorations. ${ }^{3,6,9,28}$ Nevertheless, some shortcomings have been reported for this technique. First, difficulties related to stabilizing the thin and fragile replicated space have been noted. ${ }^{8}$ In the present study, all of the silicone replicas remained in their crowns, a finding that may be attributed to the fact that silicone adheres to the rough inner surfaces of the crowns, not to the smooth surfaces of the metal dies of the prepared tooth. Another, difficulty pertains to standardizing the seating force. ${ }^{17}$ However, different seating forces do not appear to significantly affect the 
Table 3. Pairwise comparisons of tested materials

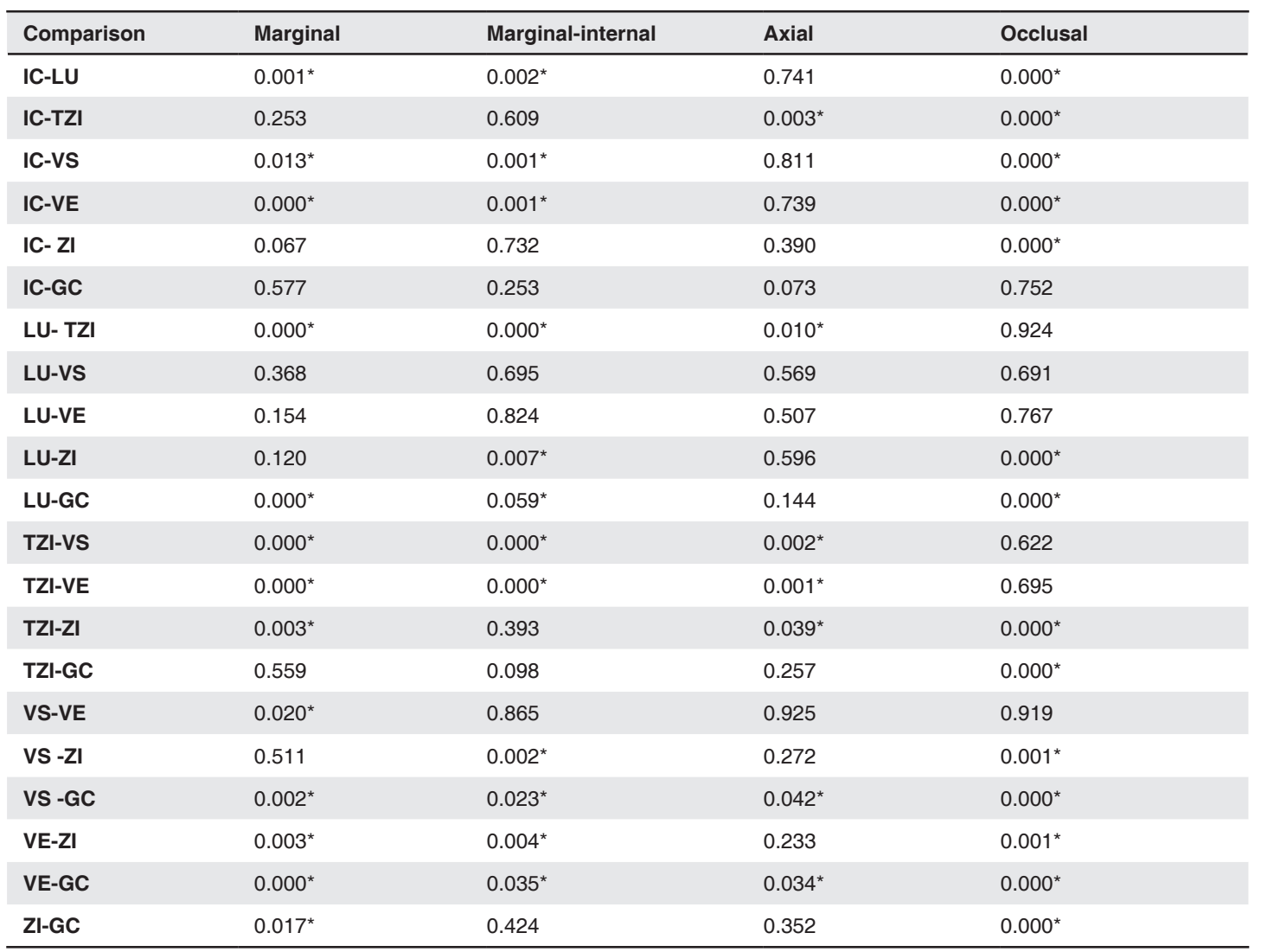

${ }^{*}$ Difference is significant between two materials (p<0.05). IC: IPS e.max CAD, LU: Lava Ultimate, TZI: Incoris TZI, VS: Vita Suprinity, VE: Vita Enamic, ZI: IncorisZI, GC: GC Cerasmart

thickness of the silicone layer. ${ }^{18}$ In this study, light-body silicone impression material was applied to the inner surface of the crowns and placed on the prepared teeth by a single operator using the same finger pressure. ${ }^{28}$

The marginal and internal adaptations of CAD/ CAM-fabricated restorations may have been affected by several factors including fabrication technique, preparation design, spacer thickness, the scanning method and its accuracy, the software, the restorative material, and the properties of milling machine. ${ }^{1}$ The aim of this study was to evaluate marginal and internal adaptations of posterior CAD/CAM crowns fabricated from contemporary restorative materials. Therefore, an effort to standardize remaining factors from abutment teeth preparation to milling of the crowns has been made. A standard tooth preparation was replicated to obtain gypsum dies that were used to fabricate the CAD/ CAM crowns. Therefore, the effects of the preparation geometry and the margin design on adaptation of crowns could be eliminated. ${ }^{3}$ Next, the gypsum dies were replicated with laser-sintering technology to obtain metal dies for measuring the adaptation of the restorations. With these metal dies, more uniform measurements could be achieved compared with natural teeth and resin dies. ${ }^{3,30}$ We opted for a chamfer preparation in light of the findings of previous studies evaluating the effect of different marginal preparation designs on the adaptation of all-ceramic restorations. These studies revealed no difference between the marginal adaptations of chamfer and shoulder margins, and the chamfer design has clinical advantages over the shoulder design. ${ }^{31-33}$ In the zirconia core group (ZI), a circumferential collar was designed in the cores to avoid the influence of a veneer layer on the marginal adaptation of crowns. CAD/CAM-fabricated feldspathic veneer luted to the zirconia core by a resin cement was preferred in the zirconia core group to eliminate the effect of firing procedures on the marginal adaptation of zirconia cores. ${ }^{34}$ The influence of different veneering methods such as conventional porcelain firing, the heatpress technique, and CAD/CAM-fabricated veneers on the internal and marginal adaptations of zirconia cores may be of interest for future research. Since we were attempting to standardize milling conditions and the quality of specimen fabrication, we used a new set of diamond burs. The cooling and lubricating fluid was also refreshed for each group of specimens. Scanning of the gypsum dies of the prepared teeth in the diagnostic casts was also performed by the same clinician using an intraoral camera (CEREC Omnicam) based on triangulation technology as its capture method.

Although marginal and internal adaptations are 
fundamental factors in the clinical success of partial fixed dental prostheses, the ideal gap for ceramic crowns is a controversial topic. ${ }^{3,35}$ Several studies have reported that marginal gap values ranging from 100$200 \mu \mathrm{m}^{2,5,36}$ and internal gaps ranging from 200-300 $\mu \mathrm{m}$ are clinically acceptable for cemented restorations. ${ }^{3,37,38}$ Considering CAD/CAM-fabricated restorations, previous studies focused on marginal and internal adaptations of zirconia copings and lithium disilicate crowns, and both materials yielded clinically acceptable marginal and internal crown adaptation results. 1,6-8,11,16,19-22 The marginal and internal gap values of zirconia copings and lithium disilicate crowns found in this study are slightly higher than those of previous studies. This finding may be due to the spacer thickness setting of $80 \mu \mathrm{m}$ used in this study. In conventional fabrication techniques, it is known that providing a space between the dies and the restorations for the cement improves adaptation. CAD/ CAM technology makes it possible to set this cement space using software. It has been reported that different settings have an impact on the resulting marginal and internal adaptation. ${ }^{13-15} \mathrm{~A}$ small gap may lead to widening the marginal gap in consequence of premature contacts between restoration and abutment tooth. ${ }^{13,39}$ Mously et al. ${ }^{1}$ evaluated the effect of spacer thickness settings on adaptation of restorations fabricated using E4D CAD/ CAM system, and the authors recommended a space thickness of 30 or $60 \mu \mathrm{m}$. However, no information is available about the effect of spacer thickness settings on adaptation of CEREC crowns. Additional studies are necessary to determine the optimum spacer thicknesses for CEREC crowns milled from different materials.

Various restorative materials for CAD/CAM systems differing in chemical structure and indications are currently available on the dental market. ${ }^{12}$ Furthermore, advances in materials have led scientists to develop new classifications for all-ceramic and ceramiclike materials. ${ }^{12,23}$ Some of these materials require additional processing after milling, necessitating specialized equipment for firing and glazing, ${ }^{25}$ other products do not necessarily require those steps and can generally be finished using the readily available armamentarium in a dental office. ${ }^{40}$ These differences in production process may affect marginal and internal adaptations of restorations. The literature does not present any information about marginal and internal adaptations of crowns milled from monolithic zirconia and resin-ceramic hybrid blocks. In this study, resinceramic hybrid materials demonstrated clinically acceptable marginal and internal adaptations; however, discrepancies were high for monolithic zirconia crowns. This excessive marginal gap may be attributed to sinterization shrinkage of thick zirconia material of the full contour of the monolithic zirconia crowns. Monolithic zirconia crowns are thicker than zirconia cores, a fact that may lead to significantly more sintering contraction. Additional studies are necessary to evaluate the effect of zirconia thickness on the adaptation of restorations.

There are some limitations to this study. Although the silicone replica technique has been accepted as a precise method to measure adaptation of restorations, the cementation process may affect the definitive marginal and internal adaptations due to differences in luting agent viscosity. Therefore, examining the marginal and internal adaptation of the crowns does not simulate the clinical conditions in this study. In the present study, we assessed the marginal and internal adaptations of single mandibular first molar crowns. Because of differences in morphology and shape, the marginal and internal adaptations may be different for anterior or premolar teeth. Furthermore, different results might have been observed if the fixed partial prostheses had been investigated in terms of precision of the adaptation instead of single crowns.

\section{Conclusion}

Within the limitations of the study, all-ceramic crown materials that are used for chair-side CAD/CAM systems demonstrated clinically acceptable marginal and internal adaptations. Gaps were higher in monolithic zirconia crowns. The lowest gap values were observed in axial areas, and the highest values were observed in occlusal areas.

\section{ACKNOWLEDGEMENTS}

This study was presented as a poster presentation at the 39th Annual Conference of the European Prosthodontic Association, Prague, Czech Republic, September 3-5, 2015. This study was supported by grant no. 114S238 from The Scientific and Technological Research Council of Turkey (TÜBITAK).

Conflict of interest disclosure: The authors declare no conflict of interest related to this study.

\section{References}

1. Mously HA, Finkelman M, Zandparsa R, Hirayama H. Marginal and internal adaptation of ceramic crown restorations fabricated with CAD/CAM technology and the heat-press technique. J Prosthet Dent 2014;112:249-56

2. Karlsson S. The fit of Procera titanium crowns. An in vitro and clinical study. Acta Odontol Scand 1993;51:129-34.

3. Souza RO, Ozcan M, Pavanelli CA, Buso L, Lombardo GH, Michida $\mathrm{SM}$, et al. Marginal and internal discrepancies related to margin design of ceramic crowns fabricated by a CAD/CAM system. J Prosthodont 2012;21:94-100

4. Rudolph $\mathrm{H}$, Luthardt RG, Walter MH. Computer-aided analysis of the influence of digitizing and surfacing on the accuracy in dental CAD/ CAM technology. Comput Biol Med 2007;37:579-87.

5. Renne W, McGill ST, Forshee KV, DeFee MR, Mennito AS. Predicting marginal fit of CAD/CAM crowns based on the presence or absence of common preparation errors. J Prosthet Dent 2012;108:310-5.

6. Martins LM, Lorenzoni FC, Melo AO, Silva LM, Oliveira JL, Oliveira $\mathrm{PC}$, et al. Internal fit of two all-ceramic systems and metal-ceramic crowns. J Appl Oral Sci 2012;20:235-40.

7. Lins L, Bemfica V, Queiroz C, Canabarro A. In vitro evaluation of the internal and marginal misfit of CAD/CAM zirconia copings. J Prosthet Dent 2015;113:205-11.

8. Pradies G, Zarauz C, Valverde A, Ferreiroa A, Martínez-Rus F. Clinical evaluation comparing the fit of all-ceramic crowns obtained from silicone and digital intraoral impressions based on wavefront 


\section{sampling technology. J Dent 2015;43:201-8.}

9. Wettstein F, Sailer I, Roos M, Hämmerle $\mathrm{CH}$. Clinical study of the internal gaps of zirconia and metal frameworks for fixed partial dentures. Eur J Oral Sci 2008;116:272-9.

10. Contrepois M, Soenen A, Bartala M, Laviole O. Marginal adaptation of ceramic crowns: a systematic review. J Prosthet Dent 2013;110:44754.

11. Kokubo Y, Tsumita M, Kano T, Sakurai S, Fukushima S. Clinical marginal and internal gaps of zirconia all-ceramic crowns. J Prosthodont Res 2011;55:40-3.

12. Gracis S, Thompson VP, Ferencz JL, Silva NR, Bonfente EA. A new classification system for all-ceramic and ceramic-like restorative materials. Int J Prosthodont 2015;28:227-35.

13. Nakamura T, Dei N, Kojima T, Wakabayashi K. Marginal and internal fit of Cerec 3 CAD/CAM all-ceramic crowns. Int J Prosthodont 2003;16:244-8.

14. Nakamura T, Tanaka $\mathrm{H}$, Kinuta $S$, Akao T, Okamoto $K$, Wakabayashi $\mathrm{K}$, et al. In vitro study on marginal and internal fit of CAD/CAM allceramic crowns. Dent Mater J 2005;24:456-9.

15. Iwai T, Komine F, Kobayashi K, Saito A, Matsumura H. Influence of convergence angle and cement space on adaptation of zirconium dioxide ceramic copings. Acta Odontol Scand 2008;66:214-8.

16. Yildiz C, Vanlioglu BA, Evren B, Uludamar A, Ozkan YK. Marginalinternal adaptation and fracture resistance of CAD/CAM crown restorations. Dent Mater J 2013;32:42-7.

17. Tamac E, Toksavul S, Toman M. Clinical marginal and internal adaptation of CAD/CAM milling, laser sintering, and cast metal ceramic crowns. J Prosthet Dent 2014;112:909-13.

18. Weaver JD, Johnson GH, Bales DJ. Marginal adaptation of castable ceramic crowns. J Prosthet Dent 1991;66:747-53.

19. Baig MR, Tan KB, Nicholls Jl. Evaluation of the marginal fit of a zirconia ceramic computer-aided machined (CAM) crown system. J Prosthet Dent 2010;104:216-27.

20. Anadioti E, Aquilino SA, Gratton DG, Holloway JA, Denry IL, Thomas GW, et al. Internal fit of pressed and computer-aided design/ computer-aided manufacturing ceramic crowns made from digital and conventional impressions. J Prosthet Dent 2015;113:304-9.

21. Sakrana AA. In vitro evaluation of the marginal and internal discrepancies of different esthetic restorations. J Appl Oral Sci 2013;21:575-80.

22. $\mathrm{Ng} \mathrm{J}$, Ruse D, Wyatt C. A comparison of the marginal fit of crowns fabricated with digital and conventional methods. J Prosthet Dent 2014;112:555-60.

23. Awada A, Nathanson D. Mechanical properties of resin-ceramic CAD/CAM restorative materials. J Prosthet Dent 2015;114:587-93.

24. Syrek A, Reich G, Ranftl D, Klein C, Cerny B, Brodesser J. Clinical evaluation of all-ceramic crowns fabricated from intraoral digital impressions based on the principle of active wavefront sampling. J Dent 2010;38:553-9.

25. Beuer F, Schweiger J, Edelhoff D. Digital dentistry: an overview of recent developments for CAD/CAM generated restorations. Br Dent J 2008;204:505-11.

26. Nedelcu RG, Persson AS. Scanning accuracy and precision in 4 intraoral scanners: an in vitro comparison based on 3-dimensional analysis. J Prosthet Dent 2014;112:1461-71.

27. Patzelt SB, Emmanouilidi A, Stampf S, Strub JR, Att W. Accuracy of full-arch scans using intraoral scanners. Clin Oral Investig 2014;18:1687-94.

28. Reich S, Uhlen S, Gozdowski S, Lohbauer U. Measurement of cement thickness under lithium disilicate crowns using an impression material technique. Clin Oral Investig 2011;15:521-6.

29. Acar Ö. Farklı yüzey hazırlıklarının CAD/CAM hibrit seramiğin kompozit rezin ile tamirine etkisi. Acta Odontol Turc 2016;33:121-5.

30. Beuer F, Aggstaller H, Richter J, Edelhoff D, Gernet W. Influence of preparation angle on marginal and internal fit of CAD/CAM-fabricated zirconia crown copings. Quintessence Int 2009;40:243-50.
31. Bindl A, Mormann WH. Marginal and internal fit of all-ceramic CAD/CAM crown-copings on chamfer preparations. J Oral Rehabil 2005;32:441-7.

32. Re D, Cerutti F, Augusti G, Cerutti A, Augusti D. Comparison of marginal fit of Lava CAD/CAM crown-copings with two finish lines. Int $J$ Esthet Dent 2014;9:426-35.

33. Krasanaki ME, Pelekanos S, Andreiotelli M, Koutayas SO, Eliades G. X-ray microtomographic evaluation of the influence of two preparation types on marginal fit of CAD/CAM alumina copings: a pilot study. Int J Prosthodont 2012;25:170-2.

34. Schmitter M, Mueller D, Rues S. In vitro chipping behaviour of allceramic crowns with a zirconia framework and feldspathic veneering: comparison of CAD/CAM-produced veneer with manually layered veneer. J Oral Rehabil 2013;40:519-25.

35. Pelekanos S, Koumanou M, Koutayas SO, Zinelis S, Eliades G. Micro-CT evaluation of the marginal fit of different In-Ceram alumina copings. Eur J Esthet Dent 2009;4:278-92.

36. Yeo IS, Yang JH, Lee JB. In vitro marginal fit of three all-ceramic crown systems. J Prosthet Dent 2003;90:459-64.

37. Sorensen JA, Munksgaard EC. Interfacial gaps of resin cemented ceramic inlays. Eur J Oral Sci 1995;103:116-20.

38. Mou SH, Chai T, Wang JS, Shiau YY. Influence of different convergence angles and tooth preparation heights on the internal adaptation of Cerec crowns. J Prosthet Dent 2002;87:248-55.

39. Hmaidouch R, Neumann P, Mueller WD. Influence of preparation form, luting space setting and cement type on the marginal and internal fit of CAD/CAM crown copings. Int J Comput Dent 2011;14:219-26.

40. Chen HY, Hickel R, Setcos JC, Kunzelmann KH. Effects of surface finish and fatigue testing on the fracture strength of CAD-CAM and pressed-ceramic crowns. J Prosthet Dent 1999;82:468-75.

\section{Hastabaşı CAD/CAM sistemi ile üretilen posterior tam seramik kronların marjinal ve internal adaptasyonlarının değerlendirilmesi: in vitro çalışma}

\section{Özet}

AmAÇ: Hastabaşı bilgisayar destekli tasarım / bilgisayar destekli üretim (CAD/CAM) teknolojisindeki ve materyal bilimindeki ilerlemeler, günümüzde anterior ve posterior dişler için estetik restorasyonların yapımını olanaklı hale getirmiştir. Ancak, üretilen yeni CAD/CAM materyallerinin marjinal ve internal adaptasyonları ile ilgili yeterince veri yoktur. Bu çalışmanın amacı; hastabaşı CAD/CAM sistemi ile üretilen posterior tam seramik restorasyonların marjinal ve internal adaptasyonlarını değerlendirmektir.

GeREÇ VE YönTEM: Yapay bir alt sağ birinci büyükazı dişi standart diş kesimi kurallarıyla prepare edildi ve prepare edilen dişlerden standart modeller oluşturuldu. Tam seramik restorasyonlar $(n=10)$, yedi farklı CAD/CAM materyalinden üretildi (IPS e.max CAD, Lava Ultimate, Incoris TZI, Incoris ZI, Vita Suprinity, Vita Enamic, ve GC Cerasmart). Örneklere ait marjinal ve internal adaptasyonlar; ince bir bistüri yardımıyla kesilen silikon replikalardan ölçüldü. Day materyali ve restorasyonun iç yüzeyi arasındaki boşluğu temsil eden silikon replika 50x büyütmeye sahip ışık mikroskobunda dijital kamera ile incelendi. Her bukkal-lingual bölümden dört referans noktası ve her mezial-distal bölümden sekiz referans 
noktası belirlenerek incelendi. Sonuçlar iki yönlü varyans analizi ve Tukey HSD testi ile değerlendirildi $(\alpha=0.05)$.

BuLGULAR: Marjinal-internal alanlarda görülen değerler genellikle marjinal alanlardaki değerlerden yüksek bulundu. Materyaller arasında anlamlı farklılıklar bulundu. İstatistik analiz sonucunda; materyal tipi ve referans noktasının lokalizasyonu arasında interaksiyon bulundu $(p<0.05)$. En düşük değerler aksiyel alanlarda ve en yüksek değerler ise oklüzal alanlarda gözlendi.

Sonuç: Bütün materyaller klinik olarak kabul edilebilir derecede marjinal ve internal uyumsuzluk gösterdi.

ANAHTAR Kelimeler: Bilgisayar yardımlı tasarım; dental marjinal adaptasyon; seramikler 